\title{
Proteins released by cultured Day 15-16 conceptuses prolong luteal maintenance when introduced into the uterine lumen of cyclic ewes
}

\author{
J. D. Godkin*†, F. W. Bazer $\ddagger$, W. W. Thatcher§ and R. M. Roberts* \\ Departments of ${ }^{*}$ Biochemistry and Molecular Biology, $\ddagger$ Animal Science and $\S$ Dairy Science, \\ University of Florida, Gainesville, Florida 32610, U.S.A.
}

\begin{abstract}
Summary. Experiments were performed to determine whether proteins, produced and released into the incubation medium by Day 15-16 sheep conceptuses cultured for 24$48 \mathrm{~h}$, could prolong the functional lifespan of the corpus luteum $(\mathrm{CL})$ when infused into the uterine lumen of cyclic ewes. Beginning on Day 12 (oestrus = Day 0) either a concentrated $(2 \mathrm{ml})$ solution of total conceptus culture medium protein $(2.2 \mathrm{mg})$ or diluted sheep serum ( $2.2 \mathrm{mg}$ protein) was introduced daily via an indwelling catheter into the uterine lumen of 3 ewes for 7 days (Days 12-18). Peripheral blood samples were collected daily for 14 days (Days 12-25). On Day 25 all ewes were laparotomized and ovaries observed to determine whether $\mathrm{CL}$ previously marked with India ink were maintained. All controls had ovulated and formed new CL. By contrast none of the conceptus protein-treated ewes had ovulated, and their peripheral progesterone levels remained elevated. One ewe maintained a functional CL until Day 52 when she was hysterectomized. Light microscopy of histological sections prepared from the endometrium revealed glandular development comparable to that in the endometrium of cyclic animals during late dioestrus. The cells of the $\mathrm{CL}$ were similar to those from cyclic animals during mid- to late dioestrus. Ovine trophoblast protein (oTP-1), a major protein secreted by the sheep conceptus between Days 13 and 21 of pregnancy, was purified from conceptus incubation medium and injected $(0.2 \mathrm{mg}$ protein/day) into the uterine lumen of 3 animals. Plasma progesterone concentrations indicated that oTP-1treated animals maintained luteal function 4 days longer than did control animals. We suggest that conceptus proteins and specifically oTP-1 are involved in the maintenance of luteal function during early pregnancy, and that this action is probably mediated through interaction with the uterine endometrium.
\end{abstract}

\section{Introduction}

In the ewe the presence of a viable conceptus in the uterus prevents regression of the corpus luteum (CL) and reproductive cyclicity which occurs in non-pregnant animals at 16-17-day intervals. In cyclic ewes the uterine endometrium produces prostaglandin (PG) F-2 $\alpha$ which is believed to be transported to the ovary in a local fashion and cause cessation of progesterone production and demise of the CL (McCracken et al., 1972). Protein products from developing ovine blastocysts have been implicated in mediating maintenance of $\mathrm{CL}$ and progesterone production during early

† Present address: Department of Animal Science, University of Tennessee, Knoxville, Tennessee 37901-1071, U.S.A.

(C) 1984 Journals of Reproduction \& Fertility Ltd 
pregnancy (Rowson \& Moor, 1967; Moor, 1968; Godkin, Cote \& Duby, 1978; Martal, Lacroix, Loudes, Saunier \& Wintenberger-Torrès, 1979; Ellinwood, Nett \& Niswender, 1979; Godkin, Bazer, Moffatt, Sessions \& Roberts, 1982; Godkin, Bazer \& Roberts, 1984). Daily injection or infusion of conceptus homogenates or extracts into the uterine lumen beginning on Day 12 have been successful in prolonging the oestrous cycle of non-pregnant ewes. The active component was reported to be heat-labile, species-specific, protease-sensitive and not present beyond Day 21 (Rowson \& Moor, 1967; Martal et al., 1979). We have identified by two-dimensional polyacrylamide gel electrophoresis proteins produced in vitro by the sheep conceptus between Days 13 and 23 of pregnancy and purified the two major secretory polypeptide products (Godkin et al., 1982; Masters et al., 1982). One of these, ovine trophoblast protein-1 (oTP-1), a low molecular weight, acidic polypeptide $\left(\mathrm{M}_{\mathrm{r}} \sim 17000-21000 ; \mathrm{pI} \sim 5.5\right)$ is produced only up to Day 21 of pregnancy, but not beyond (Godkin et al., 1982). It is the only detectable product produced at Day 13. We have also demonstrated that oTP-1 accumulates in the uterine epithelium of Day-16pregnant ewes, but does not appear to enter the maternal blood system, and that receptors for oTP1 are present on endometrium (Godkin et al., 1984). In the present study we have determined whether OTP-1 and other proteins released into the incubation medium by Day 15-16 conceptuses were capable of prolonging the functional lifespan of the $\mathrm{CL}$ when infused into the uterine lumen of cyclic ewes.

\section{Materials and Methods}

Materials. All materials employed were supplied by the vendors noted by Godkin et al. $(1982,1984)$.

Animals. Adult crossbred ewes, primarily of Rambouillet breeding, were checked twice daily for oestrus with vasectomized rams. Ewes selected as embryo donors were mated to 2 intact rams at oestrus. Ewes to be subjected to surgery were not fed for $24 \mathrm{~h}$ before surgery, but water was supplied ad libitum. Anaesthesia was induced and maintained with methoxyflurane (Metofane: PitmanMoore, Inc., Washington Crossing, NJ, U.S.A.) administered via a closed circuit gas anaesthetic unit. After a surgical plane of anaesthesia was achieved, the reproductive tract was exposed via midventral laparotomy under aseptic conditions. Blastocysts were flushed from uteri on Day 15 or 16 of pregnancy with sterile medium (MEM, see below) at $37^{\circ} \mathrm{C}$ and collected in sterile serum bottles as previously described (Godkin et al., 1982).

Medium preparation. Eagle's minimum essential medium (MEM) was prepared according to the method of Basha, Bazer \& Roberts (1979) and used as described by Godkin et al. $(1982,1984)$ for the culture of sheep and pig conceptuses and endometrial tissue explants.

In-vitro culture of conceptuses. Conceptuses were removed from the uterus under sterile conditions and transferred to Petri dishes containing $15 \mathrm{ml}$ MEM. These were incubated for 24-48 $h$ in a controlled atmosphere chamber (Bellco Biological Glassware, Vineland, NJ, U.S.A.) at $37^{\circ} \mathrm{C}$ on a rocking platform (6 cycles/min) as described previously (Godkin et al., 1982). Incubations were terminated by chilling the cultures on ice and then centrifuging at $12000 \mathrm{~g}$ for $20 \mathrm{~min}$ to separate tissue and medium which were frozen and stored $\left(-20^{\circ} \mathrm{C}\right)$ separately. Tissues from the conceptuses were not utilized in these studies.

Preparation of conceptus culture medium protein concentrate. Medium from 21 conceptus incubations $(315 \mathrm{ml})$ was dialysed $\left(\mathrm{M}_{\mathrm{r}}\right.$ cutoff $\left.\sim 12000\right)$ extensively (4 litres changed 4 times) against $10 \mathrm{~mm}$-Tris- $\mathrm{HCl}$ buffer ( $\mathrm{pH} 8 \cdot 2)$ to remove low molecular weight compounds. The dialysate was concentrated to $42 \mathrm{ml}$ with an Amicon filtration unit (UM-10 filter), redialysed against Dulbecco's phosphate-buffered saline (DPBS; Dulbecco \& Vogt, 1954), pH 7.6, filter sterilized and supplemented with penicillin $(200 \mathrm{U} / \mathrm{ml})$, streptomycin $(200 \mu \mathrm{g} / \mathrm{ml})$ and fungizone $(0 \cdot 5 \mu \mathrm{g} / \mathrm{ml})$. The final protein concentration of the concentrate was $1.1 \mathrm{mg} / \mathrm{ml}$ (Lowry, Rosebrough, Farr \& Randall, 
1951). Samples of $2 \mathrm{ml}$ of the protein concentrate of the sterile conceptus culture medium were transferred to sterile plastic snap-top Falcon tubes, quick-frozen in a solid $\mathrm{CO}_{2}$-ethanol bath and stored at $-20^{\circ} \mathrm{C}$. Serum, from cyclic ewes, was diluted in DPBS to $1.1 \mathrm{mg} / \mathrm{ml}$, dialysed against DPBS and prepared in an identical manner.

Purification of ovine trophoblast protein 1 (oTP-1) from in-vitro conceptus cultures. Conceptuses were collected from ewes on Day 16 of pregnancy and cultured in vitro as described earlier. The total protein released into culture medium is referred to as conceptus culture medium protein (CP). Ovine TP-1 was purified from the pooled medium of about 90 conceptus incubations by the procedure of Godkin et al. (1982), using a combination of diethylaminoethyl (DEAE)-cellulose ionexchange and Sephacryl S-200 gel filtration. Purified oTP-1 was prepared at a concentration of $0 \cdot 1$ $\mathrm{mg} / \mathrm{ml}$, dialysed extensively against DPBS and supplemented with penicillin $(200 \mathrm{U} / \mathrm{ml})$, streptomycin $(200 \mu \mathrm{g} / \mathrm{ml})$ and fungizone $(0.5 \mu \mathrm{g} / \mathrm{ml})$. Samples of the pure, sterile oTP $-1(0 \cdot 1 \mathrm{mg} / \mathrm{ml})$ were frozen in sterile Falcon tubes and stored at $-20^{\circ} \mathrm{C}$. Serum from cyclic ewes was prepared at $0 \cdot 1 \mathrm{mg} / \mathrm{ml}$, handled as described above and used as a control.

Introduction of the total conceptus protein and oTP-1 into the uterine lumen of cyclic ewes. Ewes were anaesthetized on Day 11 of the oestrous cycle and the uterus and ovaries were exteriorized through a midventral incision. A polyvinyl catheter (V6, BoLab, Lake Havasu City, AZ, U.S.A.; i.d. $0.86 \mathrm{~mm}$, o.d. $1.52 \mathrm{~mm}$ ) was introduced into the lumen of the oviduct ipsilateral to the CL 1-2 $\mathrm{cm}$ above the tubo-uterine junction, and the tip of the catheter fed into the uterine lumen $\sim 2 \mathrm{~cm}$ below the tubo-uterine junction. On the catheter were 3 cuffs $(\sim 0.5 \mathrm{~cm}$ wide), made out of Silastic (Dow Corning Corp., Midland, MI, U.S.A.) placed 4, 5 and $15 \mathrm{~cm}$ from the tip, which were used to secure it to the oviduct. Silk ligatures (2) were placed on either side of each cuff, securing the catheter to the exterior of the oviduct and to the uterine horn. The catheter was exteriorized through the animal's flank and the length of exteriorized cannula $(\sim 20 \mathrm{~cm})$ was stored in a plastic zip-lock pouch which had been sutured to the skin. Corpora lutea were marked by the injection of $0.1 \mathrm{ml}$ India ink using a 27 -gauge needle. After recovery from surgery ewes were confined in individual mobile crates with hay and water available ad libitum. This containment was considered necessary to prevent possible damage to the catheters, as might occur while managing unrestrained ewes.

In Exp.1, beginning on Day 12, 2-ml samples of conceptus protein or diluted sheep serum (2.2 $\mathrm{mg}$ ) were thawed, warmed to $37^{\circ} \mathrm{C}$ and slowly injected (over a $0.5 \mathrm{~min}$ period) daily into the uterine lumen of each of 3 animals. After each injection of protein solution, the cannulae were flushed with $0.5 \mathrm{ml}$ sterile $0.9 \%(\mathrm{w} / \mathrm{v}) \mathrm{NaCl}$. The treatment was continued daily for 7 days (Days 12-18) and blood samples were collected daily for 14 days (Days 12-25) for progesterone analysis. The injection of protein solution and collection of blood was performed each morning between $07: 30$ and $08: 00$ h. On Day 25, animals were laparotomized, the cannulae checked for potency and then removed, and ovaries were observed for CL marked with India ink or for new ovulations and CL formation. After recovery from surgery, animals were observed for oestrous behaviour in the presence of vasectomized rams. Before removal of the cannulae ewes were not checked for oestrus because the activity might have disturbed the indwelling cannulae.

In Exp. 2, beginning on Day 12, 2-ml samples of purified oTP-1 $(0.2 \mathrm{mg})$ or diluted sheep serum $(0.2 \mathrm{mg})$ were thawed, warmed to $37^{\circ} \mathrm{C}$ and slowly introduced daily into the uterine lumen of each of 3 ewes. This amount of oTP-1 was judged to be about equivalent to that released per Day-16 conceptus in $24 \mathrm{~h}$. All procedures were as described for Exp. 1 except that treatment was continued for 10 days (Days 12-21).

Histology. Uterine and luteal tissues from the Day 52 'pseudopregnant' ewe in Exp. 1 were fixed overnight $\left(4^{\circ} \mathrm{C}\right)$ in Bouin's fluid, dehydrated through absolute ethanol and embedded in paraffin wax. Sections were cut at $6 \mu \mathrm{m}$ and sequential sections from each tissue fixed onto gelatin-coated glass slides and stained with haematoxylin and eosin. 
Progesterone radioimmunoassay. Validation of the extraction and assay procedures were the same as those described by Knight, Bazer, Thatcher, Franke \& Wallace (1977). Plasma from a wether was assayed to assess variation in the progesterone radioimmunoassay. The mean plasma concentration for the wether was $310 \cdot 6 \pm 24 \cdot 1 \mathrm{pg} / \mathrm{ml}$. The intra- and inter-assay coefficients of variation were 17.4 and $9.1 \%$ respectively. The sensitivity of the assay was $10.0 \mathrm{pg} / \mathrm{ml}$.

Statistical analysis. Differences in the number of days that peripheral progesterone levels exceeded $1 \mathrm{ng} / \mathrm{ml}$ for treated and control ewes were tested for significance by Wilcoxon's two sample test (Steele \& Torrie, 1960).

\section{Results}

\section{Effects of intrauterine infusion of conceptus protein on luteal maintenance}

The total conceptus protein or dilute sheep serum (each at $2.2 \mathrm{mg} /$ day) was introduced into the uterine lumen of 3 sheep each for 7 days (Days 12-18). This amount of protein is about equivalent to that released per conceptus in a 24-h culture. At laparotomy on Day 25 the patency of all catheters was confirmed and there was no evidence of intrauterine infection in any of the animals. In addition, there was no evident accumulation of fluid within the oviduct. All ewes which received sheep serum had ovulated and formed new CL. None of the animals which received total conceptus protein had ovulated. Two of the animals treated with conceptus protein had maintained the marked CL, which appeared large and well vascularized. The marked CL of one conceptus proteintreated animal appeared to be in the process of regression. This CL appeared blanched and relatively avascular.

Analysis of plasma progesterone values for these animals supported the visual observations. Progesterone concentrations for all control animals declined to $<1 \mathrm{ng} / \mathrm{ml} \mathrm{15-19} \mathrm{days} \mathrm{after} \mathrm{the} \mathrm{first}$

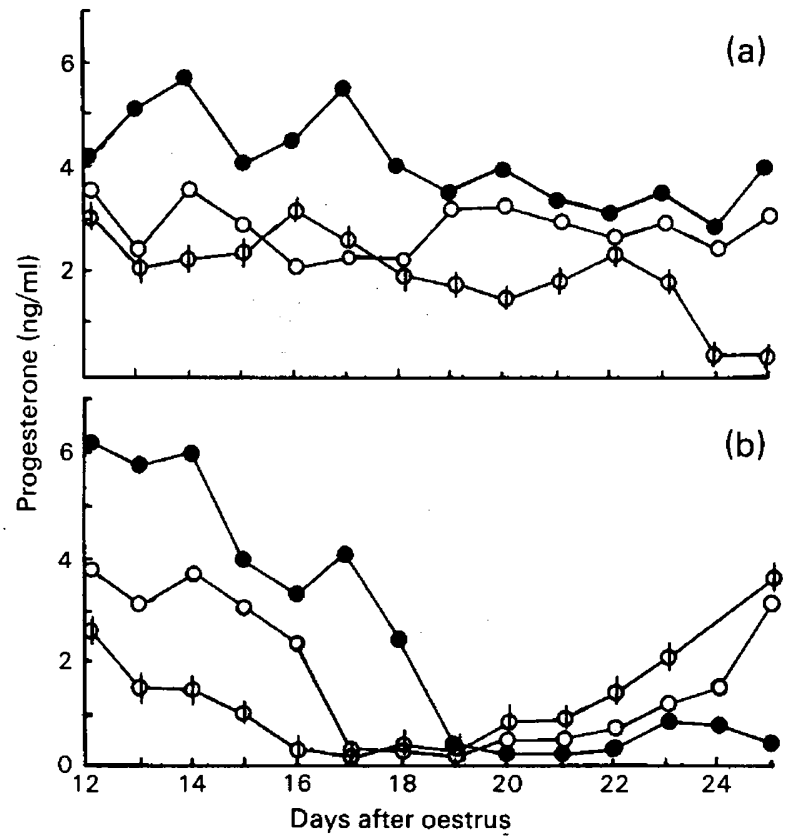

Text-fig. 1. Peripheral plasma progesterone concentrations of ewes receiving intraluminal uterine injections of (a) $2.2 \mathrm{mg}$ protein concentrate of the conceptus culture medium or (b) sheep serum ( $2 \cdot 2 \mathrm{mg}$ protein/day) for 7 days (Days 12-18). 

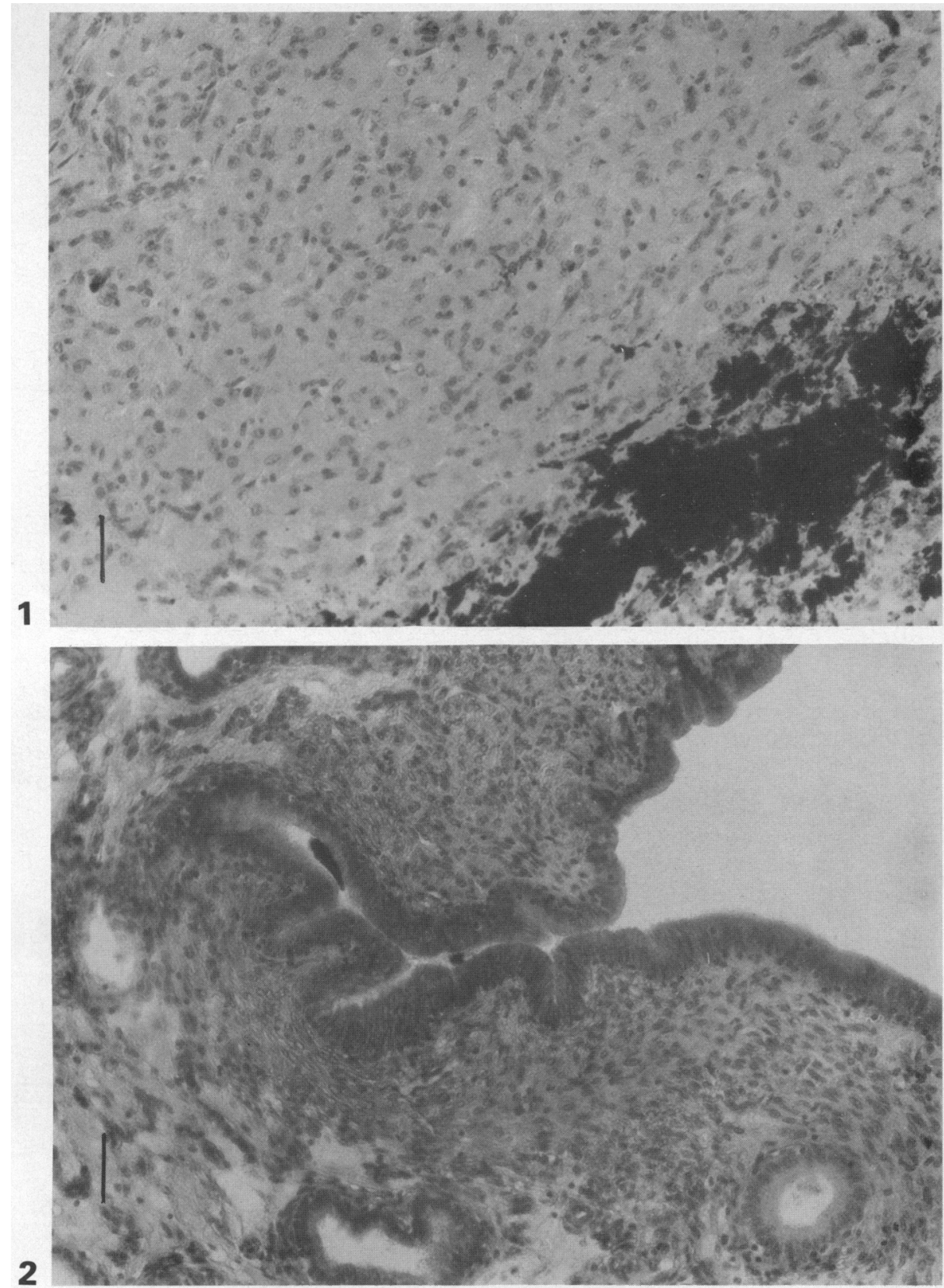

Fig. 1. Histological section from the corpus luteum of a ewe treated with conceptus protein. Oestrus had not been exhibited by Day 52 when the animal was hysterectomized and ovariectomized. The dark material at the lower right of the figure is particles of carbon originating from the India ink which was injected into the CL at the beginning of the experiment on Day 11. Note the large, well preserved luteal cells. The scale represents $20 \mu \mathrm{m}$.

Fig. 2. Histological section from the uterine endometrium of the same animal as in Fig. 1. The endometrium is highly glandular and the epithelial cells of the uterine glands are hypertrophied The scale represents $20 \mu \mathrm{m}$.

\section{(Facing p. 60)}


day of the previous standing oestrus (Text-fig. 1b). Plasma progesterone levels of the conceptus protein-treated ewes (Text-fig. 1a) remained elevated longer than in control animals $(P<0.01)$. Progesterone concentrations for the ewe with a regressing CL fell below $1 \mathrm{ng} / \mathrm{ml}$ on Day 24 . The other 2 animals with maintained CL had plasma progesterone values of 2.7 and $4.1 \mathrm{ng} / \mathrm{ml}$ on Day 25. One of these ewes exhibited standing oestrus on Day 34 and had a plasma progesterone concentration of $3.6 \mathrm{ng} / \mathrm{ml}$ on Day 31. The other ewe had not exhibited oestrous behaviour by Day 52 when she was laparotomized and the uterus and ovaries removed. The marked CL was present and appeared fully functional. Histological examination of the CL revealed that the luteal cells were normal with no indication of degeneration (P1. 1, Fig. 1). Examination of tissue sections from the uterine endometrium of this ewe by light microscopy indicated that the endometrium was highly glandular (P1. 1, Fig. 2) and typical for a dioestrous ewe.

\section{Effects of intrauterine infusion of oTP-1 on luteal maintenance}

Visual examination of the ovaries at Day 25 demonstrated that the control and oTP-1-treated animals had ovulated and formed new CL. The new CL of control animals were larger and more developed than the corpora haemorrhagica present in the ovaries of oTP-1-treated ewes. Peripheral plasma concentrations of progesterone are presented in Text-fig. 2 . In the oTP-1-treated ewes luteal function was maintained significantly longer than in control ewes $(P<0.025)$. Plasma progesterone concentrations were plotted relative to the days after oestrus for each animal. Values for all control ewes fell to basal levels $(<1 \mathrm{ng} / \mathrm{ml}) \quad 15-18$ days after the first day of the previous oestrus (Day 0). In contrast, values for oTP-1-treated ewes declined to basal levels 3-5 days later than controls. One control ewe, which maintained plasma progesterone levels above $1 \mathrm{ng} / \mathrm{ml}$ up to Day 17 , had a history of extended oestrous cycles: in the 2 cycles before the one in which this control animal was treated, cycle lengths were 18 and 19 days in duration. All other control and oTP-1treated ewes had had previous cycles of 16-17 days in length.

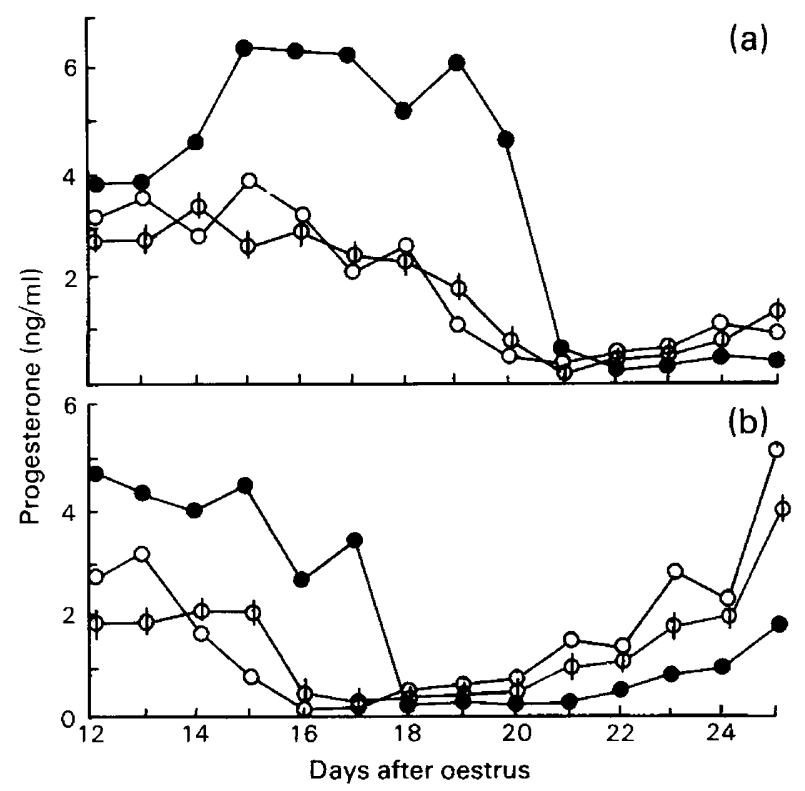

Text-fig. 2. Peripheral plasma progesterone concentrations of ewes receiving intraluminal uterine injections of (a) $0.2 \mathrm{mg}$ purified oTP-1/day or (b) $0.2 \mathrm{mg}$ sheep serum protein/day for 10 days (Days 12-21). 


\section{Discussion}

The present study is the first to demonstrate that proteins released in vitro by cultured Day-15-16 sheep conceptuses are capable of prolonging the functional lifespan of the $C L$ when delivered into the uterine lumen of cyclic ewes. In addition, we have shown that purified oTP-1, a major polypeptide synthesized by the ovine conceptus between Days 13 and 21, also extends luteal maintenance when introduced into the uterus.

Several other investigators have observed the prolongation of luteal function after the uterine infusion of sheep conceptus homogenates or extracts of homogenates (Rowson \& Moor, 1967 ; Ellinwood et al., 1979; Martal et al., 1979). Our studies differ from these in that we have utilized protein released by the conceptus during culture rather than extracts of conceptus tissue homogenates. Our rationale was that if the blastocysts signal their presence by intrauterine secretion of a specific product (or products) this material was likely to be released selectively into the medium during short-term, in-vitro incubations of conceptuses and be produced only during the period (Days 12-20) critical for the maternal recognition of pregnancy (see Godkin et al., 1982). Moreoever, we anticipated that such a product was more likely to be enriched in the culture medium than in the tissue, thus making its purification and characterization much easier. In initial experiments we demonstrated that the array of protein products released by conceptuses in culture was indeed distinct and considerably simpler than that of the tissues. In addition, the dominant proteins in the medium were very minor components in the tissue. One protein, oTP-1, appeared to be the only product released by the Day- 13 conceptus, a time when a blastocyst must be present in the uterus to prevent CL regression (Moor, 1968). The synthesis of oTP-1 also appeared to end around Day 21. Thus, the production of oTP-1 occupied the exact window during which maternal recognition of pregnancy occurs. It was for these reasons that, in addition to testing whole conceptus incubation medium, we also tested oTP-1 alone for its ability to extend CL function.

The use of proteins released by the blastocyst also enabled us to utilize a much lower concentration of material than has been used by other workers. Ellinwood et al. (1979) infused $>23$ $\mathrm{mg}$ per day of protein ( 3 embryo equivalents) derived from whole blastocyst homogenates. Rowson \& Moor (1967) employed homogenates of 1-2 embryo equivalents per day and Martal et al. (1979) utilized 3 homogenates or extracts of homogenates of 3 embryo equivalents per day. We used just $2.2 \mathrm{mg}$ of the unfractionated proteins obtained from conceptus incubations and $200 \mu \mathrm{g} \mathrm{oTP}-1$ per day. The quantity of each was estimated to be similar to that produced by a Day-16 conceptus cultured for $24 \mathrm{~h}$. These amounts were $10 \%$ and $1 \%$ those employed by Ellinwood et al. (1979).

Findlay (1981) has stressed the need for proper controls in infusion experiments such as these, since intrauterine infusion of lamb serum was associated with maintenance of the CL in a significant number of ewes. It is possible that infusing a large quantity of cellular material or protein could have similar effects. Rowson \& Moor (1967) used saline, frozen and thawed serum or white blood cells as control material but did not report whether these control infusates were at the same protein concentrations as the blastocyst homogenates: none of the control treatments prolonged CL maintenance. Ellinwood et al. (1979) and Martal et al. (1979) used saline as the control material. We used sheep serum as a control vehicle, since maternal plasma proteins are always detectable when the uterine flushings of pregnant and non-pregnant animals are analysed by two-dimensional polyacrylamide gel electrophoresis (J. D. Godkin, F. W. Bazer \& R. M. Roberts, unpublished observation) during Days 12-23. The serum was prepared at identical protein concentrations and $\mathrm{pH}$ as the conceptus medium protein.

Although total conceptus protein prolonged luteal maintenance in all ewes tested it is not clear why all of the animals did not maintain luteal function for 50 days or more. Limited quantities of the total conceptus protein permitted infusion only until Day 18. It is possible that treatment with the material until Day 21 (Days 12-21), a period corresponding with oTP-1 production by the blastocyst, would have induced a state of prolonged luteal maintenance in all animals. Alternatively, the required protein(s) may not have been present at concentrations appropriate for 
optimal effectiveness. The amounts injected daily were judged to be equivalent to those produced by a Day- 16 conceptus cultured for $24 \mathrm{~h}$, but these quantities may be far less than those secreted by a conceptus in vivo.

Ovine TP-1 was not as effective as total conceptus protein and 'prolonged' the cycle an average of only 4 days. Again, we may have supplied oTP-1 at too low a concentration to saturate the endometrial receptors (Godkin et al., 1984) and to trigger a complete response from the maternal system. Moreover, oTP-1 may have been partly degraded during purification. Another possibility is that because we applied small amounts of pure oTP-1 it was not protected adequately from proteolytic destruction within the uterus. The infusion of greater quantities of oTP-1 or the addition of protein carrier might reduce the amount of oTP-1 degradation and allow a greater quantity of active peptide to be available for interaction with the maternal tissues. Finally, it is conceivable that oTP-1 constitutes just one component of an antiluteolytic complex, and that other conceptus proteins make up the remainder of this complex.

Although it is not completely resolved whether factors from the conceptus can affect the CL directly (Godkin et al., 1978; Ellinwood et al., 1979; Hansel, 1981), most available evidence is consistent with the view that in ewes the conceptus proteins responsible for maternal recognition of pregnancy exert their effect on the uterus (Moor, 1968; Ellinwood et al., 1979; Findlay, 1981). We have previously demonstrated that oTP-1 binds specifically to a membrane fraction from the uterine endometrium, and, using immunocytochemical techniques, we have shown that it becomes localized in the upper glandular and superficial epithelium, but not in the deep glands, stroma or myometrium (Godkin et al., 1984). Moreover, it stimulates the release of proteins synthesized by uterine endometrium in vitro (Godkin et al., 1984). For these reasons, we suggest that oTP-1 may prolong the functional lifespan of the $\mathrm{CL}$ through its interaction with the uterine endometrium.

We thank Ms Candy Stoner for the radioimmunoassays, Dr P. T. K. Saunders, Dr J. Moffatt and Ms K. Fincher for surgical assistance, and Mr John Berceann for typing the manuscript.

This research was supported by Grant HD-10436 from the National Institutes of Health. University of Florida Agricultural Experimental Station Journal Series No. 4832.

\section{References}

Basha, S.M.M., Bazer, F.W. \& Roberts, R.M. (1979) The secretion of uterine specific purple phosphatase by cultured explants of porcine endometrium. Dependency upon the state of pregnancy of the donor animal. Biol. Reprod. 20, 431-441.

Dulbecco, R. \& Vogt, M. (1954) Plaque formation and isolation of pure lines with Poliomyelitis viruses. $J$. exp. Med. 99, 167-199.

Ellinwood, W.E., Nett, T.M. \& Niswender, G.D. (1979) Maintenance of the corpus luteum of early pregnancy in the ewe. I. Luteotropic properties of embryonic homogenates. Biol. Reprod. 21, 281-288.

Findlay, J.K. (1981) Blastocyst-endometrial interactions in early pregnancy in the sheep. $J$. Reprod. Fert., Suppl. 30, 171-182.

Godkin, J.D., Cote, C. \& Duby, R.T. (1978) Embryonic stimulation of ovine and bovine corpora lutea. $J$. Reprod. Fert. 54, 375-378.

Godkin, J.D., Bazer, F.W., Moffatt, J., Sessions, F. \& Roberts, R.M. (1982) Purification and properties of a major, low molecular weight protein released by the trophoblast of sheep blastocyts on Days 13-21. J. Reprod. Fert. 65, 141-150.

Godkin, J.D., Bazer, F.W. \& Roberts, R.M. (1984) Ovine trophoblast protein-1 (oTP-1) the earliest secreted blastocyst protein binds specifically to uterine endometrium and affects protein synthesis. Endocrinology (in press).

Hansel, W. (1981) Plasma hormone concentrations associated with early embryo mortality in heifers. $J$. Reprod. Fert., Suppl. 30, 231-239.

Knight, J.W., Bazer, F.W., Thatcher, W.W., Franke, D.E. \& Wallace, H.D. (1977) Conceptus development in intact and unilaterally hysterectomised-ovariectomised gilts: interrelations among hormonal status, placental development, fetal fluids and fetal growth. J. Anim. Sci. 44, 620-628.

Lowry, O.H., Rosebrough, N.J., Farr, A.L. \& Randall, R.J. (1951) Protein measurement with the Folin phenol reagent. J. biol. Chem. 193, 265-275.

Martal, J., Lacroix, M.-C., Loudes, C., Saunier, M. \& Wintenberger-Torrès, S. (1979) Trophoblastin, an antiluteolytic protein present in early pregnancy in sheep. J. Reprod. Fert. 56, 63-73.

Masters, R.A., Roberts, R.M., Lewis, G.A., Thatcher, W.W., Bazer, F.W. \& Godkin, J.D. (1982) High molecular weight glycoproteins released by expanding, pre-attachment sheep, pig and cow blastocysts in culture. J. Reprod. Fert. 66, 571-583. 
McCracken, J.A., Carlson, J.C., Glew, M.E., Goding, J.R., Baird, D.T., Green, K. \& Samuelsson, B. (1972) Prostaglandin $\mathrm{F}_{2 \alpha}$ identified as a luteolytic hormone in sheep. Nature, Lond. 238, 129-134.

Moor, R.M. (1968) Effects of embryo on corpus luteum function. J. Anim. Sci., Suppl. 1, 97-118.
Rowson, L.E.A. \& Moor, R.M. (1967) The influence of embryonic tissue homogenates infused into the uterus on the lifespan of the corpus luteum in the sheep. $J$. Reprod. Fert. 13, 511-516.

Steele, R.G.D. \& Torrie, J.H. (1960) Principles and Procedures of Statistics. McGraw-Hill, New York.

Received 20 July 1983 